\title{
防污効力の生物検定に関する研究一I 胞子テストと葉片テスト
}

\author{
宮 内 徹 夫* \\ (昭和 55 年 8 月 27 日受理)
}

\section{Laboratory Methods for the Evaluation of Antifouling Paints and Toxic Chemicals I Spore Test and Leaf Test in Fouling Algae}

Tetuo MiYauti

Miyademy Fisheries Laboratory, Futami, Watarai-gun, Mie 519-06

(Received August 27, 1980)

付着生物による污損を防ぐための船底塗料などの防污 効力を判定する方法としては，浸漬試験と呼ばれる方法 が一般に採用されているが，この浸漬試験法には，再現 性:が低いという久点とともに，その効力判定に数力月か ら 1 年以上という長期間を必要とするという大きな欠点 があり，近年，防污剤や防污塗料などの改良・開発の必 留性がたかまるに伴ない，短期間に再現性の高い結果を 出す検定法の確立が望まれている。わが国におけるこの 分野の研究では, 馬渡ら (1970) 馬渡 (1970) が多くの業 績をあげ各種の生物検定法を確立しているが，筆者は馬 渡（日本造船研究協会，1973）の「防污効力検定法の開 発確立は，防污技術発展のための必須研究である」とい ら文に触発され，10年ほど前よりアオサ，アオノリ，フ ジッボなど付着生物そのものを用いて行なら防污効力の 生物検定に関する研究を行ならとともに，多くの船底塗 料や防污剤など検定にその生物検定法を採用してきた (宮内, 1974, '75a, '75b)。

海藻類の防污いわゆる防藻の効力検定法としては, 後 述するアオサ, アオノリの葉体を用いて行なう“葉片テ スト”をすでに実用化しているが，今回，代表的な防污 剂 $\mathrm{Cu}$ と $\mathrm{Sn}$ の溶解濃度が明らかな海水を入手したのを 機会に，葉片テストの価値の再検討と胞子を用いて行な う“胞子テスト”の有効度の検討を行ならとともに, そ の胞子テストから $\mathrm{Cu}$ と $\mathrm{Sn}$ の防藻の有効濃度を求め た。その結果，二・三の知見を得たので，ここに報告す る。

* カナエ付着生物研究所・水産開発研究所

** 配偶子江多く正走光性で, 接合子及び遊走子は多 く弱い負走光性を示す（須藤，1950）
本研究に際し指導と助言を賜わった三重大学水産学部 吉田和四郎教授ならびに供試海水の提供をらけたカナエ 塗料株式会社技術部高橋一暢氏に深謝の意を表する。

\section{材料と方法}

$\mathrm{Cu} 0.30 \mathrm{ppm}, 1.90 \mathrm{ppm}$, Sn $0.41 \mathrm{ppm}, 1.91 \mathrm{ppm}$ と溶解濃度が明らかな 4 種類の海水と三重県五十鈴川河 口域にて採集したヒラアオノリ Enteromorpha compressa を用いて，胞子テストと葉片テストを行なった。

1. 胞子テスト

厚さ $0.5 \mathrm{~mm}$ の透明アクリル板にて, 長さ $55.5 \mathrm{~cm}$, 幅 $5 \mathrm{~cm}$, 深さ $10 \mathrm{~cm}$, その中に $5 \mathrm{~cm}$ 間隔で 9 枚の仕 切りを入れて，10 種類の液が収容出来るように作製し たケースを用い, 先ずそれぞれの仕切り内に $(1 / 2)^{n}$ 段階 希釈法にて希釈した 9 種類の試験液（胞子海水を加えた 際に所定の濃度になるように調整した）と対照として普 通海水を収容し, 次に別に準備したヒラアオノリの胞子 海水（葉体を採集し数時間の干出後に胞子を放出させた 海水で, 胞子放出後 1 時間以内に用いるようにした) を 加えた。

胞子注入後, ケースの側面より光を照射すると, 胞子 は光を照射した側面か逆の側面に集まるので**, 胞子が 集まる側面および底面をおおらアクリル板で作製した 形の付着板（布ヤスリで表面を傷つけ，胞子が付着しや すくした厚さ $0.5 \mathrm{~mm}$ の透明アクリル板）を入れ，そ れに胞子を付着させるよらにした。

そして，24時間後にそれら胞子を付着させた付着板を 別に用意した試験液を入れたビーカー $(500 \mathrm{cc})$ に移し, 胞子の発芽生長の状態を観察した。 


\section{2. 葉片テスト}

アオサ・アオノリの葉体より切りとった円形葉片（径 $0.7 \mathrm{~cm})$ を試験液中に浸漬し， $20^{\circ} \mathrm{C}, 1500$ ルックスと いら条件下で通気培盖して，24 時間後の葉片の伤吉度 を調べる万法を、筆者は葉片テストと呼んでいるが，今 回は, $\mathrm{Cu}$ と $\mathrm{Sn}$ の溶解濃度の明らかな 4 種類の海水を $(1 / 2)^{n}$ 段階希釈法で希釈した試験液之ヒラアオ, リの莱 片を用いて実験を行なった。

$$
\text { 結果 }
$$

\section{1. 胞子テスト}

濃厚な胞子海水を用いて头験を行ならと，24洔間後の 付着板は付着した胞子で薄い緑色を呈しているが，2 日 に 1 回の割で軽くブラシで付着板を洗滌するとともに試 験液を新らしいものと交換するといら方法で㖏篗する と, 死隇した胞子が脱色離脱するのに対し，傷害を受け ぬ胞子は数口後に発芽しはじめ濃い緑色を呈してくる。

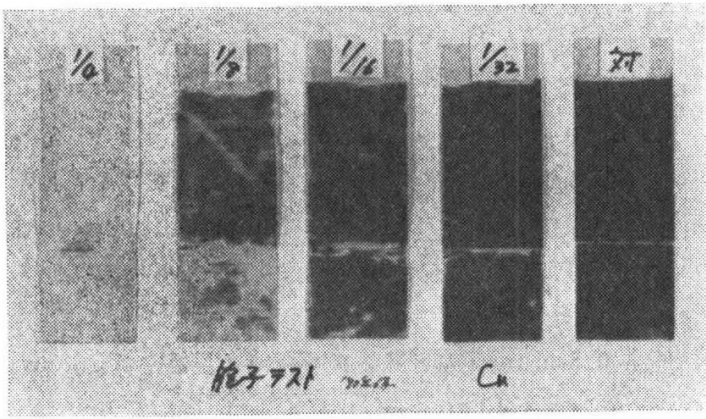

図 1. 培養 3 週間後の付着板. 胞子が発芽生辰して いる部分は濃い緑色（本図では黒色）を呈す る. 各付着板の上の分数は希橎度 (原液の $\mathrm{Cu}$ 溶解濃度は $0.30 \mathrm{ppm}$ ) を, 対は対照の普通 海水劣示与。
その結果, 2〜3 週間後には図 1 にみられる如く, 胞子の 発芽生長の度合，すなわち胞子が受けた傷害の程度は肉 眼的にも明確になる。

付着後 3 週間目の胞子の発芽生長の状態から, 付着板 を次のように分類した。すなわち，一：全胞子が死隇し ている，士：数個の胞子が発芽生長している, + : 一部 分の胞子群が発芽生長している，\#：全体にわたり発芽 生長するも対照に比し劣る, $\mathrm{H}$ ：対照と同様に発芽生烈 する。実験の結果をとりまとめると表1のとおりである。

2. 葉片テスト

浸漬 24 時間後の葉片を $0.2 \%$ エリスロシン溶液で染 色乙，その着色度合（死細胞は赤く染色される）から葉 片の傷害程度を以下のとおり分類した。一：肉眼的に傷 害が認められない， +：非常に軽い傷害で染色された小 斑がわずかに認められる， + : 葉片の $1 / 2$ 以下の部分に 傷害が認められる，姍：葉片の $1 / 2$ 以上の部分に傷宫が 認められる，姍：全体が染色されているが，傷害をうけ ぬ小斑が認められる, 曲：全体が傷害を受け完全に染色 されている。実験の結果をとりまとめると表 2 のと拈り である。

\section{考察}

本実験では，防藻効力判定法としての胞子テストの有 効性を明らかにするとともに，Cu と Sn の防藻有効濃 度を求めることが出来た。立た，すでに実用化している 葉片テストの有効性についても再確認することが出米 た。

先ず，胞子テストについてい光ば，これは防藻の対象 であるアオノリの胞子そのものを用いて行なら方法だけ に, 試験液中での胞子の培養さえ問題なく出来孔ば，て の結果が示すものは求める防藻効力そのものであるし，

表 1. $\mathrm{Cu}, \mathrm{Sn}$ 含有海水中でのヒラアオノリ胞子の発芽生長（符号：本文参照，無符号：テストなし)

\begin{tabular}{|c|c|c|c|c|c|c|c|c|c|}
\hline 希 釈 度 & 1 & $(1 / 2)^{1}$ & $(1 / 2)^{2}$ & $(1 / 2)^{3}$ & $(1 / 2)^{4}$ & $(1 / 2)^{5}$ & $(1 / 2)^{6}$ & $(1 / 2)^{7}$ & $(1 / 2)^{8}$ \\
\hline \multicolumn{10}{|c|}{1980 年 5 月 12 口 胞子付け } \\
\hline \multirow{2}{*}{$\begin{array}{l}\mathrm{Cu} \text { 濃度 }(\mathrm{ppm}) \\
\text { 発芽生長の状態 }\end{array}$} & \multirow[t]{2}{*}{0.30} & 0.150 & 0.075 & 0.0375 & 0.0188 & 0.0094 & 0.0047 & 0.0023 & 0.0012 \\
\hline & & - & + & H & 冊 & m & \# & H & \# \\
\hline \multirow{2}{*}{$\begin{array}{l}\mathrm{Sn} \text { 濃度 (ppm) } \\
\text { 発芽生長の状態 }\end{array}$} & \multirow[t]{2}{*}{0.41} & \multirow[t]{2}{*}{0.205} & 0.1025 & 0.0513 & 0.0256 & 0.0128 & 0.0064 & 0.0032 & 0.0016 \\
\hline & & & - & \pm & \pm & + & H & m & m \\
\hline \multicolumn{10}{|c|}{1980 年 7 月 10 日 } \\
\hline \multirow{2}{*}{\begin{tabular}{l|}
$\mathrm{Cu}$ 濃度 $(\mathrm{ppm})$ \\
発芽生烓の状態
\end{tabular}} & \multirow[t]{2}{*}{1.90} & \multirow[t]{2}{*}{0.95} & 0.475 & 0.2375 & 0.1188 & 0.0594 & 0.0297 & 0.0148 & 0.0074 \\
\hline & & & - & - & + & H & m & H & H \\
\hline \multirow{2}{*}{$\begin{array}{l}\text { Sn 濃度 }(\mathrm{ppm}) \\
\text { 発芽生長の状態 }\end{array}$} & \multirow[t]{2}{*}{1.91} & \multirow[t]{2}{*}{0.955} & 0.478 & 0.2388 & 0.1194 & 0.0597 & 0.0298 & 0.0149 & 0.0075 \\
\hline & & & & \pm & \pm & \pm & \pm & + & H \\
\hline
\end{tabular}


表 2. $\mathrm{Cu}, \mathrm{Sn}$ 含有海水中でのヒラアオノリ葉片細胞の傷蹇度（符号：本文参照, 無符号 : テストなし）

\begin{tabular}{|c|c|c|c|c|c|c|c|c|c|}
\hline 希 釈 度 & 1 & $(1 / 2)^{1}$ & $(1 / 2)^{2}$ & $(1 / 2)^{3}$ & $(1 / 2)^{4}$ & $(1 / 2)^{5}$ & $(1 / 2)^{6}$ & $(1 / 2)^{7}$ & $(1 / 2)^{8}$ \\
\hline \multicolumn{10}{|c|}{ テスト実施日：1980 年 5 月 12 日〜 14 日 } \\
\hline \multirow[t]{2}{*}{$\mathrm{Cu}$ 濃度 $(\mathrm{ppm})$} & 0.30 & 0.150 & 0.075 & 0.0375 & 0.0188 & 0.0094 & 0.0047 & 0.0023 & 0.0012 \\
\hline & HWH & 册 & H & - & - & - & - & - & - \\
\hline \multirow[t]{2}{*}{ 儌雪 度 } & HWH & HWH & $H$ & - & - & - & - & - & - \\
\hline & HWI & H & + & - & - & - & - & - & - \\
\hline \multirow[t]{4}{*}{ Sn 濃度 (ppm) } & 0.41 & 0.205 & 0.1025 & 0.0513 & 0.0256 & 0.0128 & 0.0064 & 0.0032 & 0.0016 \\
\hline & & & 曲 & 曲t & 册 & \# & - & - & - \\
\hline & & & 曲 & 冊州 & 册 & H & - & - & - \\
\hline & & & 曲 & HWH & 曲 & m & - & - & - \\
\hline \multicolumn{10}{|c|}{ テスト笑施日：1980 年 7 月 10 日〜12 日 } \\
\hline \multirow[t]{2}{*}{$\mathrm{Cu}$ 濃度 $(\mathrm{ppm})$} & 1.90 & 0.95 & 0.475 & 0.2375 & 0.1188 & 0.0594 & 0.0297 & 0.0148 & 0.0074 \\
\hline & & 冊 & 曲 & 曲 & H & - & - & - & - \\
\hline \multirow[t]{2}{*}{ 信 霍度 } & & 曲 & 册 & 册 & H & - & - & - & - \\
\hline & & 曲 & 冊 & 册 & H & - & - & - & - \\
\hline \multirow[t]{4}{*}{$\mathrm{Sn}$ 港度 $(\mathrm{ppm})$} & 1.91 & 0.955 & 0.478 & 0.2388 & 0.1194 & 0.0597 & 0.0298 & 0.0149 & 0.0075 \\
\hline & & & & 曲 & 曲t & 曲 & 冊 & H & - \\
\hline & & & & 册 & 冊 & 曲 & 世 & - & - \\
\hline & & & & 曲 & 曲 & 曲 & 曲 & + & - \\
\hline
\end{tabular}

防藻効力判定法としての価值が高いことはいらまでもな いが，本実験にて，その胞子の培養が比較的容易に行な い得ることが明らかになった。すなわち,この胞子テス トは，胞子そのものを用いるために周年採用し得ないと いら久点はあるものの，胞子の入手が容易な時期には比 較的手軽に採用し得る防藻効力判定法であるということ が，本実験によって確認された。

ところで， $\mathrm{Cu}$ と $\mathrm{Sn}$ の防藻有効濃度であるが，裴 1 にみられる如く, $\mathrm{Cu}$ では 2 回の実験結果はかなりよく 一致しており $0.15 \mathrm{ppm}$ 付近に有効濃度の存在するこ とが考えられたのに対し，Sn の場合には，5 月の东験 では $0.1025 \mathrm{ppm}$ で全胞子の死隇がみられたのに対し, 7月の夷験時にはわずか数個体ではあったが $0.2388 \mathrm{ppm}$ といら濃度でも発芽生長するものがみられ，両者間にか なりの差が認められた。この差の原因としては，ヒロ八 ノヒトエグサ Monostroma latissimum の胞子培養に て配偶子の生残率が接合子に比しかなり低いことが知ら れている（喜田，1973）ことから，配偶子と接合子の抵 抗力の差に起因していることも考えられるが，仮にそう であれば今度は $\mathrm{Cu}$ の結果に疑問が生じることとなる し，また本実験では，用いた胞子を配偶子，接合子，遊 走子というように戦密に分類していなかっただけにこ の点についての議諭は今後に残すこととする。

ただ，表中にて士で示したものについていえば，数
千〜数万以上の胞子の内のわずか数個が生残り発芽した のみで，その発芽生長も対照に比しはるかに状態が悪 く，そのまま生長し続け得るかどらかかなり疑問視さ れ，少なくとも防藻塗料などの効力を判定する立場から いえば，無視してよいと判断される状態であった。そこ

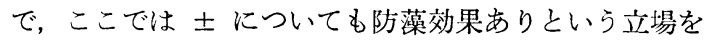
とることにするが，そのような立場から表 1 そると，

$\mathrm{Sn}$ の有効濃度は $0.02 \mathrm{ppm}$ 付近に存在することにな り，5月と 7 月の実験結果はよく一致してくる。

次に，葉片テストについていうと，表 2 にられる如 く, 胞子テストでみた防藻有効濃度と葉片に 冊, すな わち葉片の全体が傷害をらけているが傷害をらけぬ小斑 も認められるという傷害をもたらす濃度とはかなりよく 一致している。すなわち, 防藻有効濃度＝冊という関係 がみられるが, ただこの関係は, 葉片の抵抗力に季節差 が認められる (宮内，未発表）ことからすれば，周年そ のまま成立することはないといえる。

しかし，ここで安全度を考え，防藻有效濃度＝州とい ら立場をとれば，その葉片の抵抗力の季節差もほとんど カバーし得るし, 過去に多く実施してきた葉片テストに よる防藻効力判定の結果と东際の海での浸漬試験の結果 との関係ともよく一致してくる。いいかえれば, 本実験 にて, 防藻効力の有無判定㧍よび防藻効力の強弱判定の 手段としての葉片テストの有効性を再確認するととも 
に，その存效濃度の判定に際しては 册を基準におくべ きであるということが明確になったといえる。

最後に，胞子テストと葉片テストを比較してみると， 胞子テストについては，直接的・実際的方法であり，そ の点では最も優れた方法といえるが，そのテストに用い る胞子を入手し得る時期が限られているだけに周年を通 じて採用でき始といら久点も有するといらことが出来よ ら。それに対し，葉片テストの場合には，ヒラアオノリ リ，ウスバアオノリ，アナアオサなどの葉体を使いわけ れば周作その材料の入手汇は事欠かぬし，何よりも24時 間といら短時間で結果を出し得るといら大きな長所があ るだけに，周年を通じて自由に多量の胞子を入手する力 法が確立されていない現在では，多くの船底塗料や防污 凨などの効力を検定する乎段としては，葉片テストが胞 子テストよりも数段優れた生物検定法であるといらこと が出来よら。

\section{要約}

防污効力の生物検定法としての胞子テストと菜片テス トの有效性について検討するとともに，胞子テストから $\mathrm{Cu}$ と $\mathrm{Sn}$ の防藻有効濃度を求めた。

1. 試験液中での胞子の培荃は比較的容易であり, 胞 子テストが生物検定法として有効なことを認めた。
2. 防藻の有效濃度として, $\mathrm{Cu} 0.15 \mathrm{ppm}$ 程度, $\mathrm{Sn}$ $0.02 \mathrm{ppm}$ 程度といら值を得た。

3. 葉片テストの生物検定法としての有效性を再確認 するとともに, 過去の实績を併せて, 防藻効力の生物検 定法として特に優れていると判断した。

\section{文献}

玨田和四郎（1973）。ヒトエグサの人工採苗の手引き。 三重県漁連・三重県のり養殖研究会, 1-18.

馬渡静夫・北村晴男 (1970)。船底防污塗料汇関する生 物学的研究 1. 各種防污瑇物の生物検定. 資源研㝝 報, No. 73, 67-102.

馬渡静夫 (1970). 船底防污叙料阅年方生物学的研究 2. 溶出毒物の生物検定. 同誌, No. $74,80-101$.

宮内徽夫 (1974). 防污菒剂の生物検定一一防藻効力の 検定法について。叙装と叙料, No. 243, 49-56.

宮内徹夫 (1975a). 船底叙料の防污検定法に関する一 提案. 同誌, No. 249, 29-33.

宫内徹夫 (1975b). 防污薬剂の生物検定一防落効力 の受託検定について。同誌，No. 257，53-58.

山本造船研究協会 (1973). 第 141 研究部会・安全性の 高い長期防污叙料の開発研究・報告書 (1), 研究资 料 No. 186-1, 1-100.

須藤俊造 (1950)，海藻の胞子の放出・散布及び着生に 関する研究. 海藻胞子付けの研究第 8 報. 日水誌, $16(1), 1-9$. 